\title{
Kontrowersje na temat klasyfikacji histopatologicznej anomalii naczyniowych u dzieci
}

\author{
Aneta Wnęk, Józef Kobos, Przemysław Przewratil
}

Głównym problemem diagnostyki i leczenia guzów naczyniowych oraz wad układu naczyniowego jest brak jednolitej klasyfikacji, usystematyzowanej dla wszystkich specjalistów zajmujących sie tym zagadnieniem. Istniejące do tej pory klasyfikacje histopatologiczne i kliniczne są rozbieżne, często nadużywają określenia „naczyniak”, który jest guzem okresu niemowlęcego. Prowadzi to do nieprawidłowych rozpoznań, wpływając niekorzystnie na dalszy przebieg choroby i podjęte leczenie. W pracy przedstawiono i opisano polecaną przez autorów klasyfikację Międzynarodowego Towarzystwa Badań nad Anomaliami Naczyniowymi (ISSVA) i porównano ją z klasyfikacją histopatologiczną guzów naczyniowych wg WHO oraz klasyfikacją nowotworów tkanek miękkich wg Towarzystwa Onkologii Klinicznej. Ponadto omówiono nowoczesne metody rozpoznawania naczyniaków i malformacji naczyniowych, ze szczególnym uwzględnieniem obrazu histologicznego.

\section{Controversies on the histopathological classification of vascular anomalies in children}

The main problem of diagnosis and treatment of haemangiomas and of vascular system defects is the lack of unified classification, systemised for all the specialists dealing with this issue. Existing histopathological and clinical classifications are inconsistent, often overusing the term haemangioma which is an infancy tumour. This can lead to an incorrect diagnosis which affects the course of the illness and the treatment. In this paper the authors describe the recommended classification of the International Society for the Study of Vascular Anomalies (ISSVA), and compare it with histopathological classification of vascular tumours by WHO, and soft tissue tumour classification by the Association of Clinical Oncology. Furthermore, current methods of diagnosing vascular tumours and malformations are also discussed, with specific consideration of histopathological imaging.

NOWOTWORY Journal of Oncology 2015; 65, 3: 214-220

Słowa kluczowe: naczyniaki, malformacje naczyniowe, guzy naczyniowe klasyfikacja histopatologiczna, klasyfikacja onkologiczna

Key words: haemagnioma, vascular malformations, vascular tumour histopathological classification, oncology classification

\section{Wstęp}

Problem diagnostyki i leczenia anomalii naczyniowych u dzieci wydaje się być często marginalizowany, ograniczony do wąskiej grupy specjalistów zajmujących się tym zagadnieniem. W odczuciu autorów wymaga on jednak szerszego omówienia ze względu na istotną liczbę leczonych pacjentów oraz znaczne rozbieżności obowiązujących klasyfikacji histopatologicznych oraz klinicznych, prowadzące do

Pracownia Leczenia Anomalii Naczyniowych

Klinika Chirurgii i Onkologii Dziecięcej

Uniwersytetu Medycznego w Lodzi

Powyższa publikacja jest finansowana $\mathrm{z}$ funduszu $\mathrm{z}$ grantu MNiSzW Nr 507/1-123-01/507-10-005

Numer rejestracyjny projektu badawczego: N N407 691340 
wątpliwych lub nieprawidłowych rozpoznań. Problemy rodzi również stosowanie odmiennych lub wręcz nieaktualnych klasyfikacji anomalii naczyniowych przez różnych specjalistów, np. onkologów, laryngologów, chirurgów plastycznych i naczyniowych, neurochirurgów i radiologów. W pracy tej omówione zostaną następujące klasyfikacje:

- klasyfikacja Międzynarodowego Towarzystwa Badań nad Anomaliami Naczyniowymi (ISSVA),

- klasyfikacja histopatologiczna guzów naczyniowych wg WHO,

- klasyfikacja nowotworów tkanek miękkich wg Towarzystwa Onkologii Klinicznej.

\section{Klasyfikacja ISSVA i przebieg kliniczny naczyniaków oraz malformacji naczyniowych}

Naczyniaki stanowią najczęstsze guzy u dzieci; dotyczą od 5 do $10 \%$ wszystkich niemowląt, z przewagą dziewczynek w stosunku 3-9:1. Lokalizują się głównie w powłokach ciała, z najczęstszym umiejscowieniem na głowie oraz tułowiu. Przy urodzeniu może być widoczne żywoczerwone znamię lub teleangiektazja, które ulegają gwałtownemu wzrostowi w ciągu kilku tygodni. Od 10-12 miesiąca życia rozpoczyna się spontaniczne zanikanie, trwające od 3 do 10 lat. W przebiegu naczyniaków wyróżnia się zatem fazę proliferacji, inwolucji i fazę poinwolucyjną, które to różnią się między sobą obrazem histologicznym. W 40-50\% przypadków naczyniak pozostawia bliznę lub zniekształcenie po zaniku. W wybranych przypadkach konieczne jest leczenie miejscowe lub ogólne [1-5].

Podstawy klinicznej klasyfikacji naczyniaków oparte na ich biologii i budowie histologicznej podał w 1981 roku Mulliken i Głowacki, oddzielając je od malformacji naczyniowych [4]. Modyfikacja tej klasyfikacji z 1996 roku włączyła naczyniaki do szerszej grupy guzów naczyniowych [6, 7]. Uznano wówczas, że dobrze znany zespół Kassabacha-Merritta mógł być związany z guzami angioblastoma lub Kaposiform hemangioendothelioma, nie zaś z infantile hemangioma. W kwietniu tego roku w Melbourne w Australii odbyło się 20 posiedzenie The International Society for the Study of Vascular Anomalies (ISSVA), na którym została opracowana i uaktualniona nowa klasyfikacja wad naczyniowych, dzieląca się na dwie główne grupy: guzy naczyniowe i malformacje naczyniowe (tab. I).

Dla odróżnienia malformacje naczyniowe dotyczą 1-2\% dzieci i stanowią absolutnie odrębną grupę wad wrodzonych naczyń, chociaż pierwotnie swoim wyglądem mogą niekiedy przypominać naczyniaki. Podstawą ich podziału jest typ tworzących je naczyń (włosowate, tętnicze, żylne, limfatyczne, mieszane) oraz charakter przepływu naczyniowego. Są one obecne przy urodzeniu, rosną proporcjonalnie do masy ciała i nigdy nie zanikają. Wymagają zupełnie innego postępowania niż naczyniaki [5, 6, 8]. Warto wspomnieć, iż istnieje również klasyfikacja hamburska, wywodząca się ze środowiska chirurgów naczyniowych, która pozostaje w zgodzie z ww., a ponadto uwzględnia szczegóły kliniczne i embriologiczne, warunkujące podjęcie właściwego leczenia.

W praktyce klinicznej różni specjaliści posługują się różnymi klasyfikacjami odnoszącymi się do guzów naczyniowych i malformacji. Wynikają one ze szczególnych lokalizacji (mózg, twarzoczaszka, skóra) oraz utrwalonych tradycji, które nie zawsze nadążają za aktualnym stanem wiedzy. Przedstawiony powyżej podział ISSVA zyskuje coraz większe uznanie większości klinicystów, głównie chirurgów dziecięcych, pediatrów, onkologów i dermatologów leczących pacjentów z anomaliami naczyniowymi. Różnią się one jednak znacznie od przyjętej przez WHO klasyfikacji guzów naczyniowych, którą posługują się patolodzy (tab. II).

\section{Obraz histologiczny naczyniaków (ryc. 1 i 2)}

Naczyniaki w obrazie histologicznym są mieszaniną komórek śródbłonka (CD31+), pericytów $(S M A+)$, komórek dendrytycznych (czynnik XII+) i mastocytów, które w fazie proliferacji tworzą zbitą sieć naczyń kapilarnych, często z wirtualnym światłem. Mastocyty, jak i komórki śródbłonka wykazują wówczas silną ekspresję polipeptydów angiogennych, jak E-selektyna, urokinaza, kolagenaza IV, naczyniowy śródbłonkowy czynnik wzrostu (VEGF — vascular endothelial growth factor) i fibroblastyczny czynnik wzrostu (bFGF — basic fibroblastic growth factor) [9-11]. W fazie inwolucji zanikają komórki śródbłonka i podścieliska, ustępując miejsca tkance włóknisto-tłuszczowej. Komórki śródbłonka przechodzą w formę dojrzałą, światło naczyń włosowatych staje się bardziej widoczne, a ich liczba zmniejsza się. Błona podstawna tych naczyń ulega pogrubieniu i laminacji. Przemiany te mają związek z aktywacją granulocytów zasadochłonnych i nasilającym się procesem apoptozy. Wykazano również, iż komórki śródbłonka naczyniaka w fazie inwolucji wykazują ekspresję szeregu markerów obecnych również w komórkach łożyska, takich jak GLUT-1 (erythrocyte type glucose transporter), antygen Lewis Y, Fc $\gamma$ RII i merozynę. Markery te są unikalne dla naczyniaków i nie występują w malformacjach naczyniowych. GLUT-1 jest natomiast wykorzystywany do diagnostyki różnicowej naczyniaków (pozytywny w 100\%) i innych guzów naczyniowych, włączając naczyniaki wrodzone, śródbłoniaki czy "tufted angioma” (negatywny). Należy również pamiętać, że proliferacja i inwolucja nie wykluczają się wzajemnie i mogą występować w tym samym naczyniaku jednocześnie [12].

\section{Obraz histologiczny malformacji naczyniowych Malformacje żylne}

Malformacje te stanowią konglomerat naczyń żylnych, które zapadają się w czasie operacji. Ich światło jest nieregularne, a ściany znacznie ścieńczałe, z ubytkami warstwy 
Tabela I. Aktualna międzynarodowa klasyfikacja anomalii naczyniowych według ISSVA (International Society for the Study of Vascular Anomalies) dotycząca naczyniaków i malformacji naczyniowych (niektóre nazwy guzów naczyniowych nie mają polskich odpowiedników)

\begin{tabular}{|c|c|}
\hline \multicolumn{2}{|l|}{ Anomalie naczyniowe (vascular anomalies) } \\
\hline Guzy naczyniowe (vascular tumors) & $\begin{array}{c}\text { Malformacje naczyniowe } \\
\text { (vascular malformations - VM) }\end{array}$ \\
\hline Guzy łagodne & Proste \\
\hline —-Naczyniak wczesnodziecięcy/niemowlęcy (Infantile hemangioma) & Włosowate (CM) \\
\hline \multirow[t]{2}{*}{ — Naczyniak wrodzony } & Limfatyczne (LM) \\
\hline & Żylne (VM) \\
\hline Szybko znikający naczyniak wrodzony (RICH) & Tętnicze (AM) \\
\hline Niezanikający naczyniak wrodzony (NICH) & Tętniczo-żylne (AVM) \\
\hline —Wrodzony endokrynny potworniak naczyniowy & Tętniczo-żylne przetoki (AVF) \\
\hline \multicolumn{2}{|l|}{ - Tufted angioma } \\
\hline \multicolumn{2}{|l|}{$\begin{array}{l}\text { — Naczyniakośródbłoniak wrzecionowatokomórkowy } \\
\text { (spindle cell hemangioendothelioma) }\end{array}$} \\
\hline \multicolumn{2}{|l|}{$\begin{array}{l}\text { - Inne rzadkie naczyniakośródbłoniaki } \\
\text { (epitelioid, composite, retiform, polymorphous etc.) }\end{array}$} \\
\hline \multicolumn{2}{|l|}{ Pozostałe } \\
\hline Lokalnie złośliwe guzy & Mieszane \\
\hline — Naczyniakośródbłoniak o typie mięsaka Kaposiego (Kaposiform hemangioendothelioma) & CVM, CLM, LVM, \\
\hline —-Siatkowaty hemangioendothelioma & CLVM, \\
\hline —-Brodawkowaty wewnątrzlimfatyczny & AVM-LM \\
\hline —-Angioendothelioma & CM-AVM \\
\hline —-Mieszany hemangioendothelioma & CLVAVm \\
\hline \multirow[t]{2}{*}{ —Pozostałe } & Malformacje dużych naczyń \\
\hline & Związane z pozostałymi anomaliami \\
\hline \multicolumn{2}{|l|}{ Guzy złośliwe } \\
\hline \multicolumn{2}{|l|}{ - Angiosarcoma } \\
\hline \multicolumn{2}{|l|}{ —Epithelioid hemangioendothelioma } \\
\hline — Pozostałe & \\
\hline
\end{tabular}

CVM - Zespół Klippela-Trenaunaya, CLM — Sturge'a-Webera, LVM — Parkesa-Webera, CLVM - Rendu-Oslera-Webera, Maffuciego, Hippla-Lindaua, blue rubber bleb nevus syndrome, ataksja teleangiektazja

mięśniowej. W niektórych z nich mogą pozostawać wcześniejsze zakrzepy lub kamienie żylne. Badanie immunohistochemiczne $z$ anty-alfa SMA ujawnia uszkodzoną strukturę ściany z ubytkami mięśni gładkich. Anomalie te mogą obejmować prawie wszystkie narządy (ryc. 3, 4).

\section{Malformacje tętniczo-żylne}

Zmiany tego typu tworzą naczynia różnego kalibru, luźno rozmieszczone w tkance z relatywnie grubymi ścianami. Wśród naczyń znajdują się tętnice, żyły oraz liczne naczynia o pośrednim lub nieokreślonym charakterze. Naczynia kapilarne występują równie często, tworząc zrazikowe skupiska lub pozostając luźno rozrzucone w polu widzenia (ryc. 5).

\section{Malformacje limfatyczne}

Struktura histologiczna tych anomalii jest podobna do malformacji żylnych. Naczynia są cienkościenne, nieco bar- dziej okrągłe, z niewielką liczbą połączeń. Światło zawiera surowiczy płyn z dużą liczbą limfocytów, które naciekają również przylegające do malformacji tkanki (ryc. 6, 7).

\section{Malformacje kapilarne}

U pacjentów pediatrycznych malformacje te tworzą poszerzone kapilary w powierzchownej warstwie siateczkowatej skóry, przy czym ich liczba jest prawidłowa. U dorosłych liczba przekrojów naczyniowych w preparacie zwiększa się, a poszerzone kapilary o pogrubiałych ścianach znajduje się w głębszej warstwie siateczkowatej skóry. W zmianach hipertroficznych kapilary są liczniejsze i większe, wypełniając całą skórę (ryc. 8).

Obraz poszczególnych malformacji naczyniowych jest dość charakterystyczny, jednak w świetle różnorodnej manifestacji klinicznej i klasyfikacji WHO rozpoznanie patologa rozmija się niekiedy z diagnozą kliniczną. 
Tabela II. Klasyfikacja WHO guzów naczyniowych

\begin{tabular}{|c|c|}
\hline \multicolumn{2}{|c|}{ Vascular tumours } \\
\hline Benign & $\begin{array}{l}\text { Hemangiomas of subcut/deep soft } \\
\text { tissues: }\end{array}$ \\
\hline & — capillary \\
\hline & - cavernous \\
\hline & - arteriovenous \\
\hline & — venous \\
\hline & —intramuscular \\
\hline & — synovial \\
\hline & Epithelioid haemangioma \\
\hline & Angiomatosis \\
\hline & Lymphangioma \\
\hline $\begin{array}{l}\text { Intermediate } \\
\text { (locally aggressive) }\end{array}$ & Kaposiform haemangioendothelioma \\
\hline \multirow{4}{*}{$\begin{array}{l}\text { Intermediate } \\
\text { (rarely metastasizing) }\end{array}$} & Retiform haemangioendothelioma \\
\hline & $\begin{array}{l}\text { Papillary intralymphatic } \\
\text { angioendothelioma }\end{array}$ \\
\hline & Composite haemangioendothelioma \\
\hline & Kaposiform sarcoma \\
\hline \multirow[t]{2}{*}{ Malignant } & Epithelioid haemangioendothelioma \\
\hline & Angiosarcoma of soft tissues \\
\hline
\end{tabular}

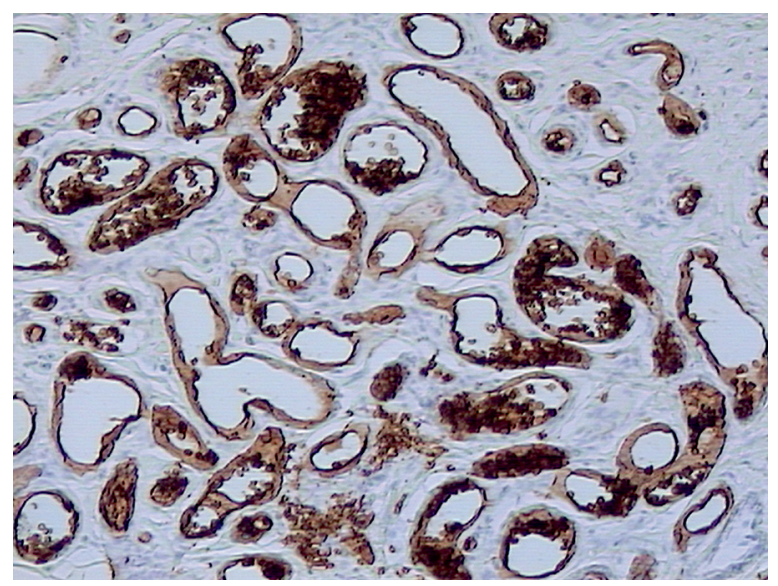

Rycina 1. Naczyniak wczesnodziecięcy — obraz histologiczny

\section{Klasyfikacja guzów naczyniowych wg WHO}

Klasyfikacja ta wydaje się wewnętrznie spójna i uzasadniona rokowniczo. Dzieli ona guzy naczyniowe na łagodne, pośrednie (lokalnie agresywne i rzadko przerzutujące) oraz złośliwe (tab. II). Stoi jednak w dużej sprzeczności z klasyfikacją ISSVA, bowiem nie rozdziela naczyniaków od malformacji naczyniowych, a wręcz łączy je czy stosuje te rozpoznania wymiennie (np. venous hemangioma czy arteriovenous hemangioma) [13].

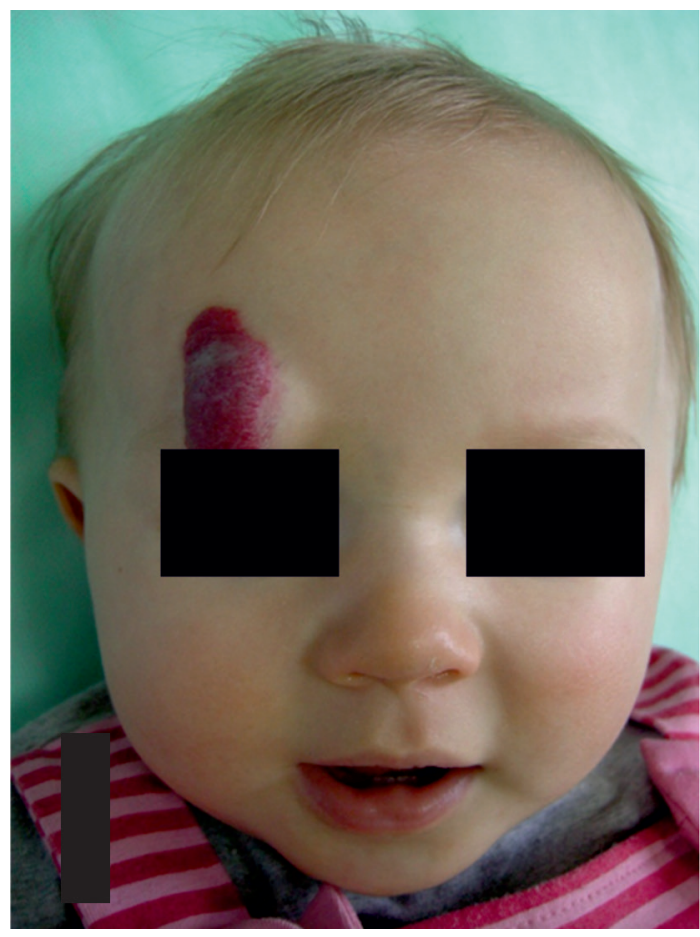

Rycina 2. Naczyniak wczesnodziecięcy u 5-miesięcznego chłopca

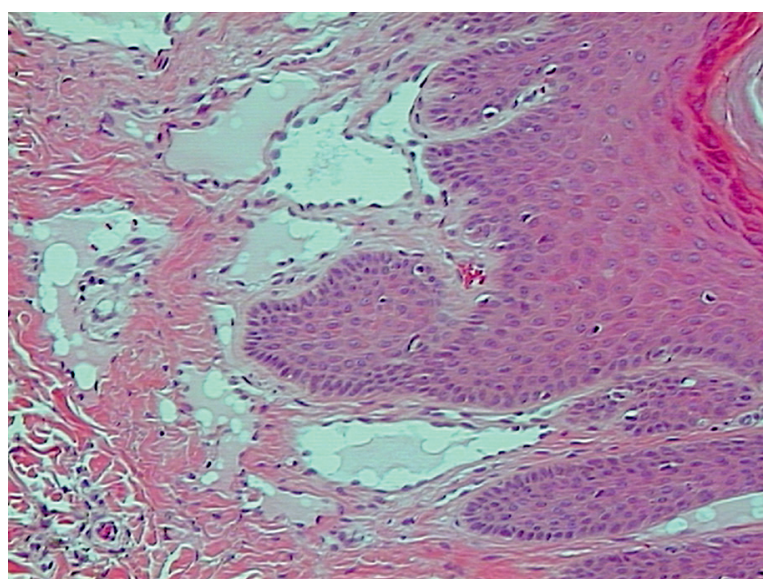

Rycina 3. Malformacja żylna — obraz histologiczny

W praktyce klinicznej autorów zdarzało się, że malformację limfatyczną rozpoznawano jako naczyniak wewnątrzmięśniowy (intramuscular hemangioma), a malformację żylną jako naczyniak jamisty. Ziarniniak krwionośny (pyogenic granuloma), który jest częstym nabytym guzem naczyniowym, rozpoznawano jako naczyniak wczesnodziecięcy (juvenile hemangioma)lub kapilarny (capillary hem angioma). Nieścisłości te, wynikające z klasyfikacji, a nie niekompetencji patologa, mogą sugerować, że naczyniak, który powinien 


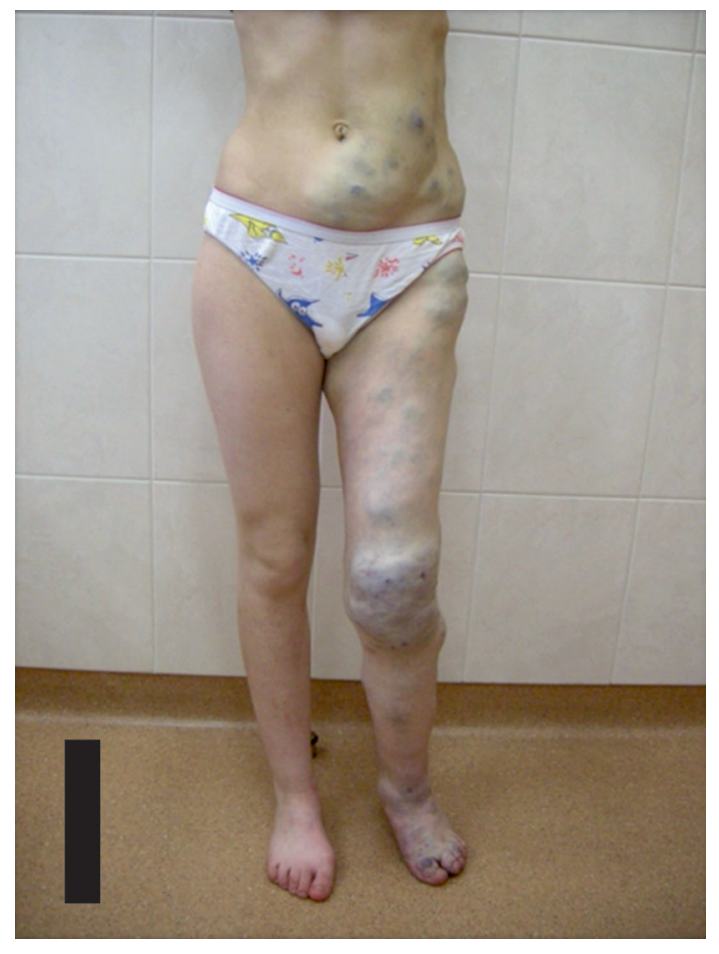

Rycina 4. Malformacja żylna połowy ciała u 16-letniej dziewczynki

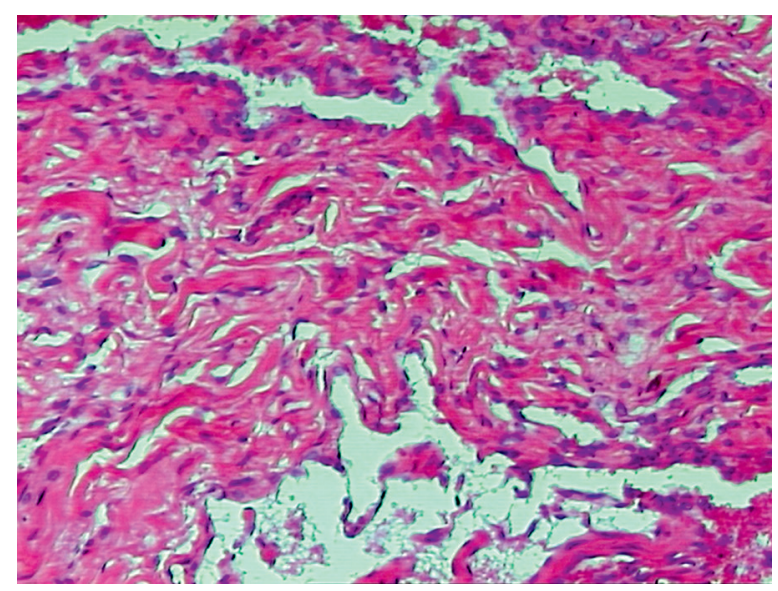

Rycina 5. Malformacja tętniczo - żylna obraz histologiczny

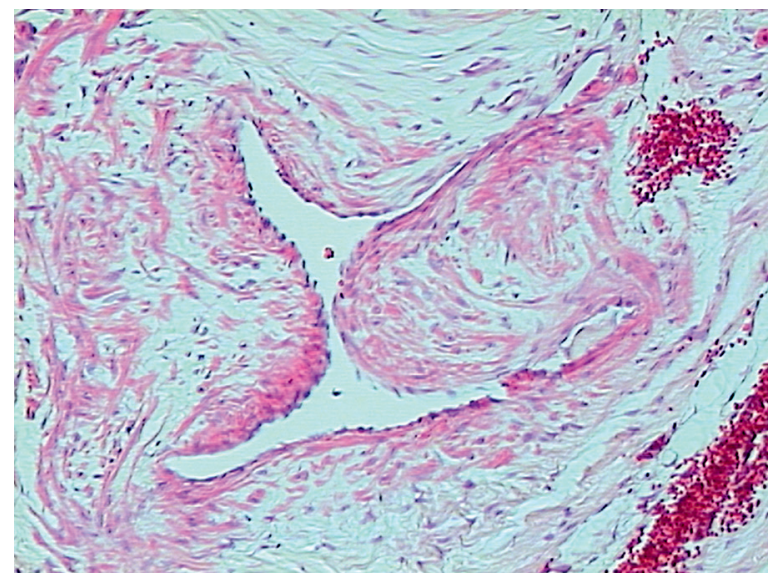

Rycina 6. Malformacja limfatyczna - obraz histologiczny

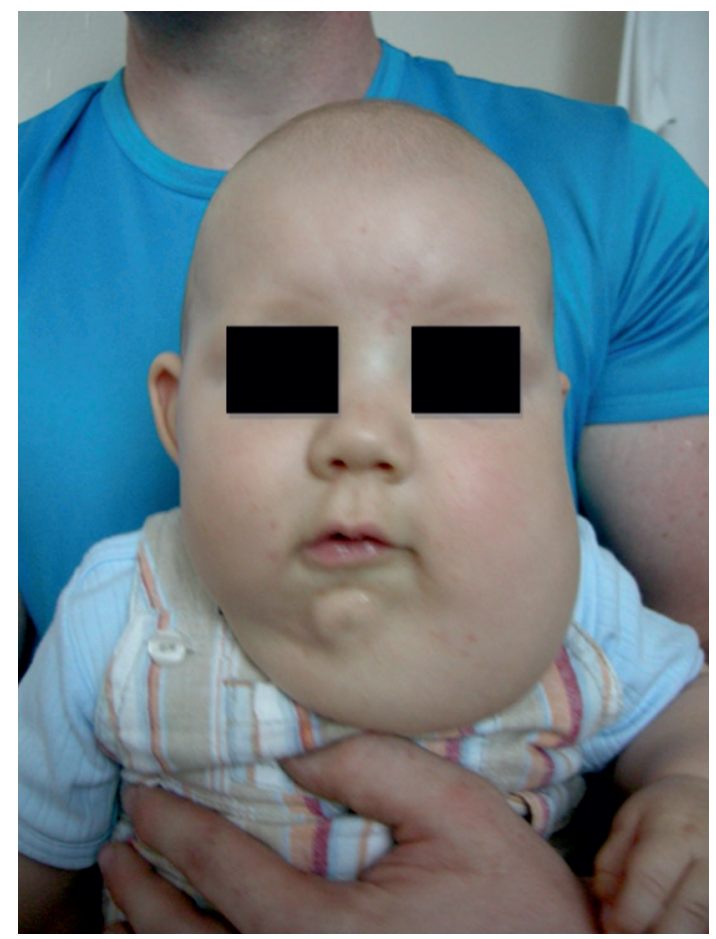

Rycina 7. Malformacja limfatyczna twarzoczaszki u 6-miesięcznego niemowlęcia

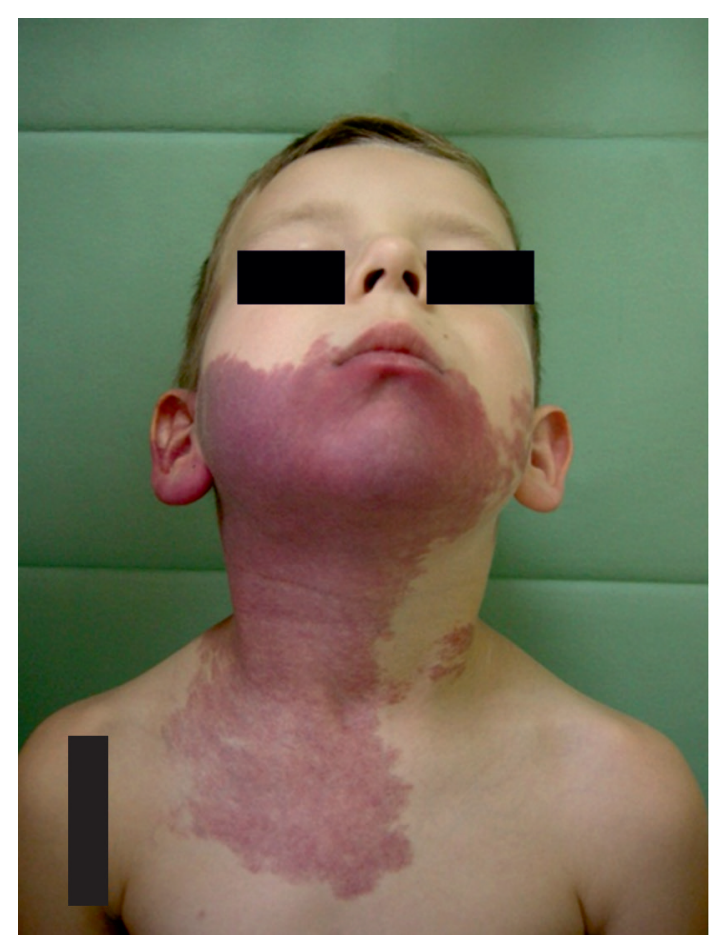

Rycina 8. Malformacja kapilarna twarzy i szyi u 4-letniego chłopca

ulegać samoistnej regresji, niepotrzebnie został zoperowany. Doniesienia takie, weryfikujące poprzednie rozpoznania, pojawiły się również w czasopismach patologicznych [14]. W niektórych przypadkach właściwe rozpoznanie histopatologiczne wymaga dodatkowych informacji, takich jak: 
Tabela III. Najczęściej spotykane nowotwory tkanek miękkich (W. Ruka 2001)

\begin{tabular}{|c|c|c|}
\hline Typ tkanki & Nowotwory złośliwe & Nowotwory łagodne \\
\hline \multirow[t]{14}{*}{ Naczynia krwionośne } & Mięsak n. krwionośnych śródbłonka & Śródbłoniak n. krwionośnych \\
\hline & Mięsak n. krwionośnych z pericytów & Mięśniak n. krwionośnych z pericytów \\
\hline & Mięsak n. krwionośnych & Naczyniak krwionośny \\
\hline & & — włośniczkowy \\
\hline & & - jamisty \\
\hline & & — żylny \\
\hline & & - groniasty \\
\hline & & — syn. rozgałęziony \\
\hline & & — śródmięśniowy \\
\hline & & — uogólniony \\
\hline & & Naczyniakowatość \\
\hline & & Kłębczak \\
\hline & & Naczyniakomięśniak \\
\hline & & Ziarniniak ropny \\
\hline \multirow[t]{3}{*}{ Naczynia chłonne } & Naczyniakomięsak limfatyczny & Naczyniak limfatyczny \\
\hline & & Naczyniakomięśniak limfatyczny \\
\hline & & Mięśniakowatość n. limfatycznych \\
\hline
\end{tabular}

czas pojawienia się zmiany, dynamika wzrostu, topografia, kolor, obraz śródoperacyjny. Jeśli takich danych brakuje, patolog może wydać wynik wstępny do czasu przedyskutowania danego przypadku z chirurgiem. Badaniem pomocniczym z pewnością będą markery tkankowe dla anomalii naczyniowych, wśród których należy wymienić GLUT-1. Jest to glikoproteina błonowa, stanowiąca uznany marker dla naczyniaków wczesnodziecięcych, stosowana już rutynowo w ośrodku autorów pracy [15]. Warto również wspomnieć o wysoce specyficznych markerach dla śródbłonka limfatycznego, jak D2-40 czy LYVE-1, służących do różnicowania malformacji limfatycznych, od innych malformacji naczyniowych [16].

\section{Klasyfikacja nowotworów tkanek miękkich wg Polskiego Towarzystwa Onkologii Klinicznej}

Przykładem innej klasyfikacji jest podział, który funkcjonuje w onkologii klinicznej pacjentów dorosłych, gdzie anomalie naczyniowe traktowane są jako łagodne nowotwory tkanek miękkich, a malformacje naczyniowe nazywane są naczyniakami [17]. Gdyby nawet uznać, że naczyniak jest formą łagodnego guza o unikalnym przebiegu, to większość malformacji naczyniowych żadnego kryterium nowotworu nie spełnia (np. CM czy VM), ponieważ stanowią one wady wrodzone obwodowego układu naczyniowego. Tabela III przedstawia fragment klasyfikacji nowotworów dotyczącej naczyń krwionośnych i limfatycznych. Warto wspomnieć, iż różni się ona nie tylko od klasyfikacji ISSVA, ale również klasyfikacji WHO guzów tkanek miękkich i kości. Pojawiają się w niej rozpoznania zupełnie nieznane dla ww. klasyfikacji, co powoduje tym większy chaos w nomenklaturze.

\section{Podsumowanie i wnioski}

Właściwe rozpoznanie histopatologiczne w przypadku anomalii naczyniowych może określać dalszy przebieg choroby i w istotny sposób wpłynąć na podjęte leczenie, zwłaszcza gdy diagnoza kliniczna jest wątpliwa. Stanowi również potwierdzenie rozpoznania klinicznego dla lekarza prowadzącego oraz rodziców leczonego dziecka. Kluczem do tego rozpoznania jest znajomość klasyfikacji ISSVA oraz wola jej stosowania, do czego autorzy niniejszej publikacji gorąco zachęcają. Klasyfikacja ta stanowi wspólną platformę dla wielu specjalistów do leczenia i badania anomalii naczyniowych, pomimo iż jest tak mało rozpowszechniona wśród patologów.

\section{Podziękowania}

Szczególne podziękowania dla Kliniki Chirurgii i Onkologii Dziecięcej, Uniwersytetu Medycznego w Łodzi pod kierownictwem prof. dr hab. n. med. Ewy Andrzejewskiej oraz istniejącej w Klinice Pracowni Leczenia Anomalii Naczyniowych pod kierownictwem dr. hab. n. med. Przemysława Przewratila za możliwość udostępnienia zarówno materiałów fotograficznych, jak i dydaktycznych oraz wykorzystania preparatów naczyniowych do powstania powyższej publikacji.

Serdeczne podziękowania dla pracowników Zakładu Patomorfologii Wieku Rozwojowego, UM w Łodzi oraz kie- 
rownika powyższej placówki prof. dr. hab. n. med. Józefa Kobosa za wsparcie merytoryczne i chęć współtworzenia publikacji.

\section{Konflikt interesów: nie zgłoszono}

\section{Mgr inż. Aneta Wnęk}

ul Turoszowska 22/8, 91-025 Łódź

e-mail:aneta_wnek@wp.pl

Otrzymano: 12 listopada $2014 \mathrm{r}$.

Przyjęto do druku: 5 lutego 2015 r.

\section{Piśmiennictwo}

1. Bauland CG, van Steensel MA, Steijlen PM i wsp. The pathogenesis of hemangiomas: a review. Plast Reconstr Surg 2006; 117: 29e-35e.

2. Sun ZJ, Zhao YF, Zhang WF. Immune response: A possible role in the pathophysiology of hemangioma. Med Hypoth 2007; 68: 353-355.

3. Bruckner AL, Frieden IJ. Hemangiomas of infancy. J Am Acad Dermatol 2003; 48: 477-493.

4. Smolinski KN, Yan AC. Hemangiomas of infancy: clinical and biological characteristics. Clin Pediatr (Phila) 2005; 44: 747-766.

5. Enjolras O, Wassef M, Chapot R. Color Atlas of vascular tumors and vascularmalformations. Cambridge: Cambridge University Press, 2007.
6. Mulliken JB, Glowacki J. Hemangiomas and vascular malformations in infants and children: a classification based on endothelial characteristics. Plast Reconstr Surg 1982; 69: 412-422.

7. Chang MW. Updated classification of hemangiomas and other vascular anomalies. Lymphat Res Biol 2003; 1: 259-265.

8. Przewratil P. Współczesne poglądy na temat skórnych anomalii naczyniowych. Przegl Pediatr 1999; 29: 22-27.

9. Takahasi K, Mulliken JB, Kozakewich HP i wsp. Cellular markers that distinguish the phases of hemangioma during infancy and childhood. J Clin Invest 1994; 93: 2357-2364.

10. Frischer JS, Huang J, Serur A. Biomolecular markers and involution of hemangiomas. J Pediatr Surg 2004; 39: 400-404.

11. Tan ST, Wallis RA, He Y i wsp. Mast cells and hemangioma. Plast Reconstr Surg 2004; 113: 999-1011.

12. Razon MJ, Kräling BM, Mulliken JB i wsp. Increased apoptosis coincides with onset of involution in infantile hemangioma. Microcirculation 1998; 5: 189-195.

13. Pathology and genetics of tumours of soft tissue and bone. Edited by Fletcher ChDM, Unni KK, Mertens F. Lyon: IARC Press, 2002: 155-175.

14. Al-Adnani M, Williams S, Rampling D i wsp. Histopathological reporting of paediatric cutaneous vascular anomalies in relation to proposed multidisciplinary classification system. J Clin Pathol 2006; 59: 1278-1282.

15. Leon-Villapalos J, Wolfe K, Kangesu L. GLUT-1: an extra diagnostic too to differentiate between haemangiomas and vascular malformations. Br J Plast Surg 2005; 58: 348-352.

16. Galambos $C$, Nodit L. Identification of lymphatic endothelium in pediatric vascular tumors and malformations. Pediatr Dev Pathol 2005; 8: 181-189.

17. Ruka W. Mięsaki tkanek miękkich. W: Krzakowski M (red.). Onkologia kliniczna, T. II. Warszawa: Borgis Wyd. Med., 2001: 342. 